This item was submitted to Loughborough's Research Repository by the author.

Items in Figshare are protected by copyright, with all rights reserved, unless otherwise indicated.

\title{
Formulation by membrane emulsification
}

PLEASE CITE THE PUBLISHED VERSION

http://www.springerreference.com/

PUBLISHER

(C) Springer

VERSION

AM (Accepted Manuscript)

LICENCE

CC BY-NC-ND 4.0

REPOSITORY RECORD

Vladisavljevic, Goran T., and R.G. Holdich. 2012. "Formulation by Membrane Emulsification”. figshare. https://hdl.handle.net/2134/10605. 
This item was submitted to Loughborough's Institutional Repository (https://dspace.lboro.ac.uk/) by the author and is made available under the following Creative Commons Licence conditions.

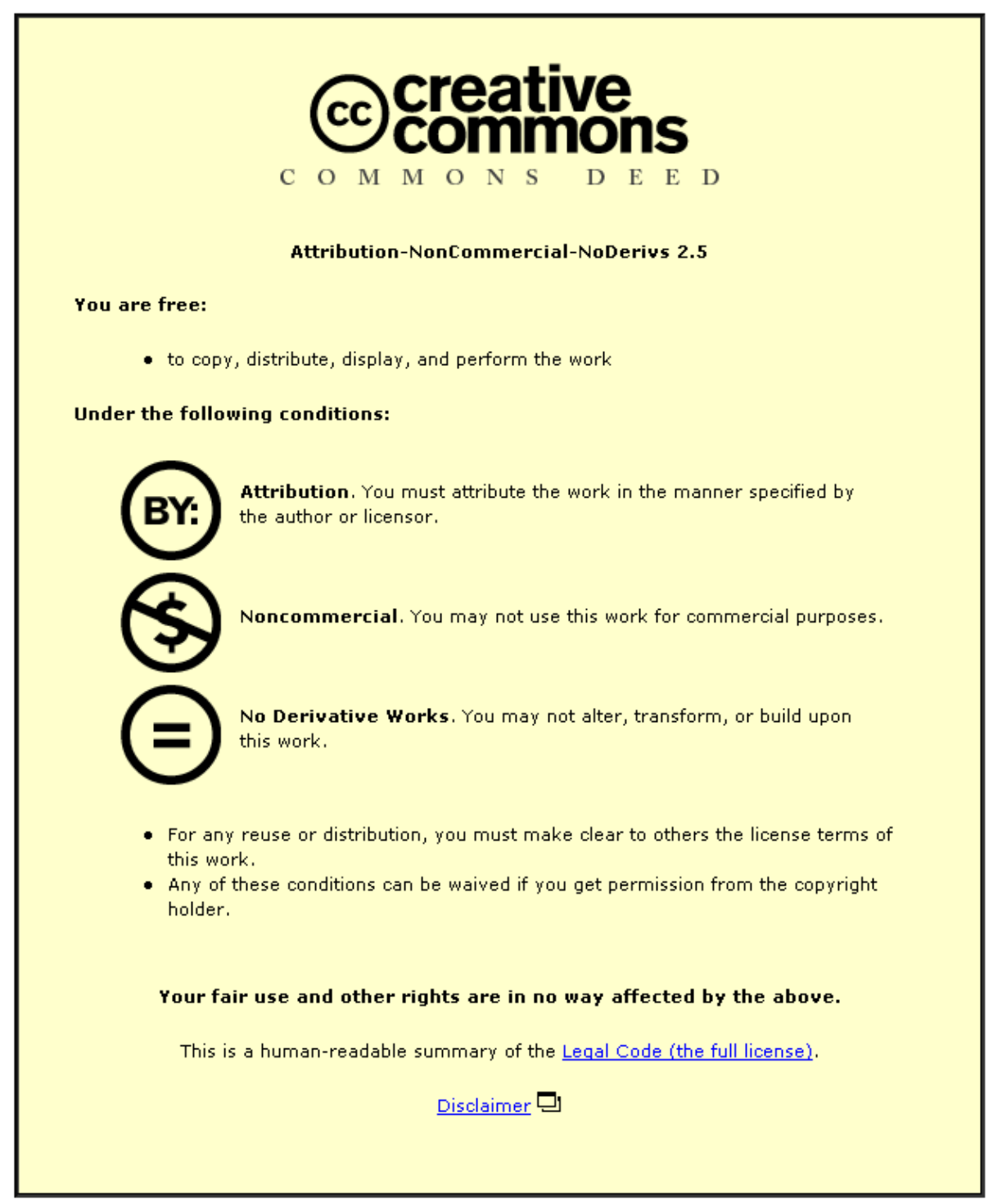

For the full text of this licence, please go to: http://creativecommons.org/licenses/by-nc-nd/2.5/ 


\section{Formulation by membrane emulsification}

Goran T. Vladisavljević, Richard G. Holdich

Chemical Engineering Department, Loughborough University, Loughborough, Leicestershire, LE11 3TU, United Kingdom.

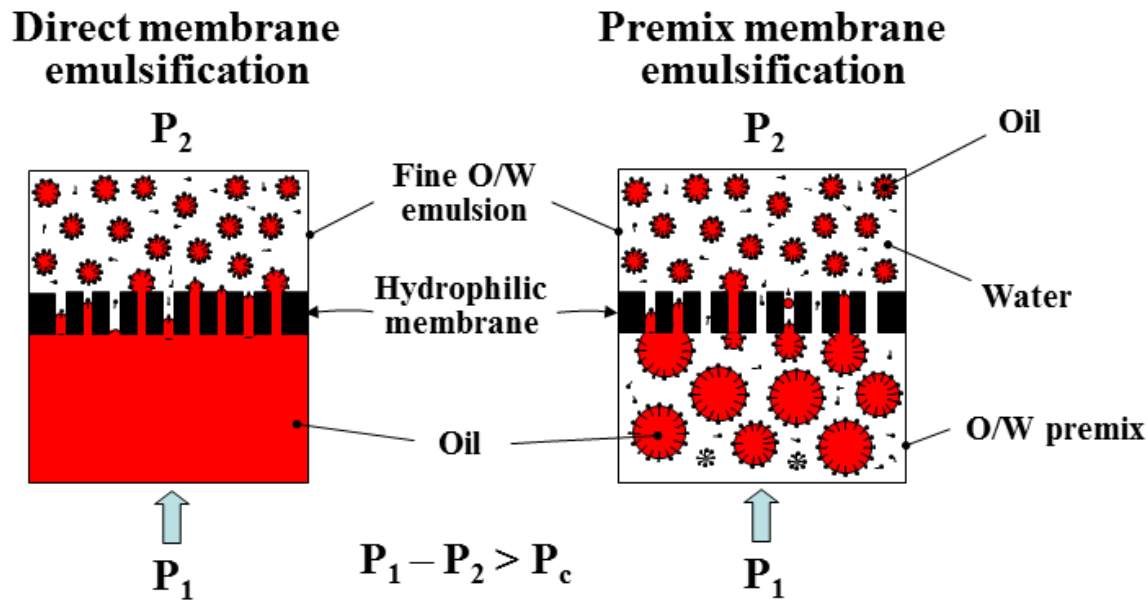

Figure 1. Two different approaches used to obtain fine droplets of oil-in-water emulsion in membrane emulsification (ME): (a) “bottom-up” approach (direct ME); (b) “Top-down” approach (premix ME).

Membrane emulsification (ME) is a process of forming emulsion by passing a pure dispersed phase or pre-emulsion through a microporous membrane (Fig. 1). The most commonly used membranes for ME are Shirasu Porous Glass (SPG) membrane and microsieve membranes. In direct $\mathrm{ME}$, fine droplets are produced at the membrane/continuous phase interface by injecting a pure liquid (the dispersed phase) through the membrane into a second immiscible liquid (the continuous phase) (Nakashima et al. 1991). The dispersed phase should not wet the membrane wall, i.e. hydrophobic and hydrophilic membranes are used to produce waterin-oil and oil-in-water emulsions, respectively. At low transmembrane fluxes, uniform droplets can be formed without applying any shear on the membrane surface, solely by the action of interfacial tension (Kukizaki 2009). In order to achieve commercially significant throughputs in $\mathrm{ME}$, the shear stress is applied at the continuous phase/membrane interface, usually by cross flow or stirring (Fig. 2 a-d). Cross-flow systems are easy to scale up and can offer a continuous operation and constant shear stress along the membrane surface. Stirring systems are operated batchwise, do not provide constant shear stress on the membrane 
surface, but are easier to operate because a closed loop recirculation of the continuous phase stream is not needed and a batch size can be very low, just $10 \mathrm{~mL}$ or even less.

The shear stress can also be generated by dynamic membrane (Fig. 1e) or pulsed flow (Fig. 1f), in which case the droplet detachment from the membrane surface is facilitated by rotating (Vladisavljević and Williams 2006) or vibrating (Holdich et al. 2010) the membrane within the otherwise static continuous phase or providing periodic flow pulsations in the continuous phase (Holdich 2012). In the dynamic and pulsed flow membrane systems, the shear stress on the membrane surface is decoupled from the cross-flow velocity and consequently, sufficiently high shear stress can be achieved at any cross flow velocity and emulsions with high dispersed phase concentrations can be produced in a single pass through the module.
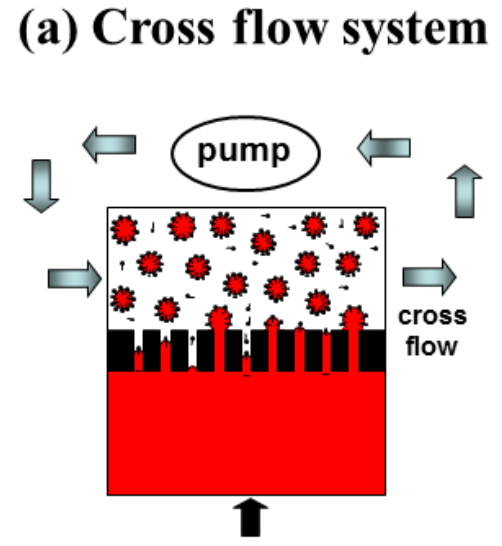

(d) Rotating flat membrane

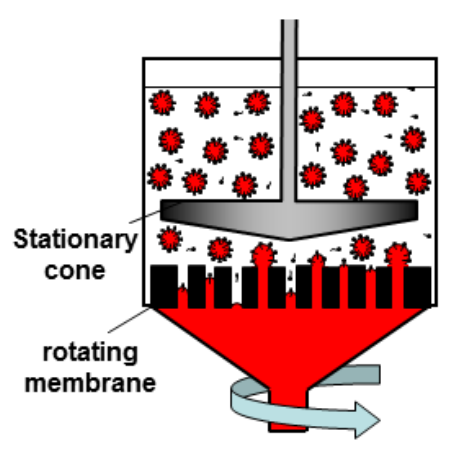

(b) Stirred cell - tube membrane

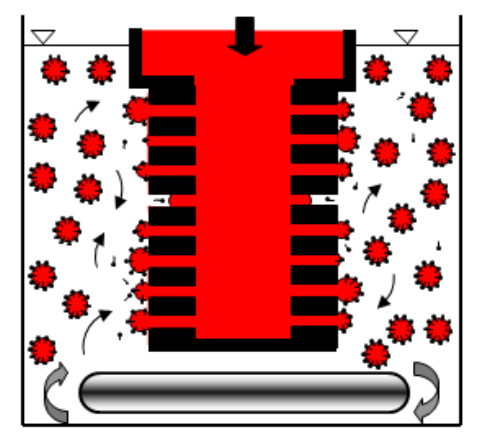

(e) Vibrating/rotating tube membrane

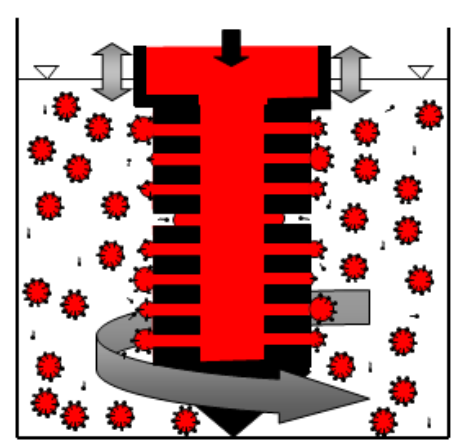

(c) Stirred cell - flat membrane

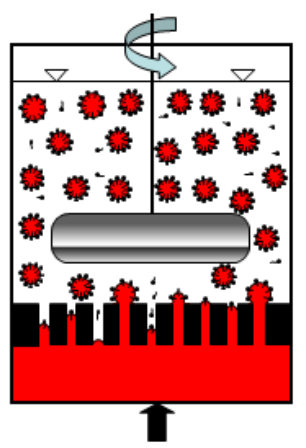

(f) Pulsed flow ME

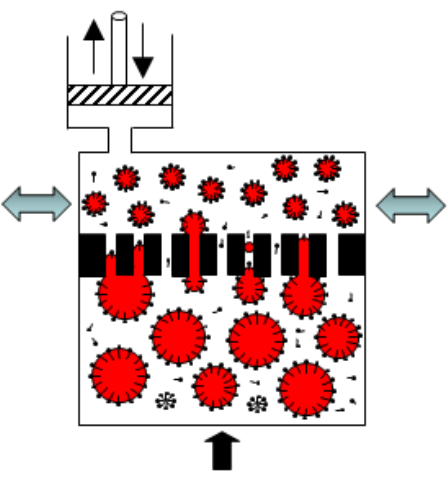

Figure 2. Different ME systems used to control shear stress on membrane surface.

In the dripping regime, the droplet size is determined by a balance between the shear force and the capillary force. The size of the droplets produced is mainly affected by the 
microstructure of the membrane (the pore size distribution, pore shape, and spacing), transmembrane flux, surface shear stress, physical properties of the continuous and dispersed phase, and emulsion formulation. Surfactant molecules must not adsorb to the membrane surface and thus, cationic surfactants must not be used in association with negatively charged membrane (such as SPG membrane and oxidised silicon microsieves) (Nakashima et al. 1993). The transmembrane pressure should not exceed 10 times the capillary pressure and the shear stress on the membrane surface is usually in the range from 2 to $10 \mathrm{~Pa}$ (Vladisavljević et al. 2004). The droplet size is typically $2-10$ times higher than the pore size and decreases with increasing the shear stress on the membrane surface.

Holdich RG, Dragosavac MM, Vladisavljević GT, Kosvintsev SR (2010) Membrane emulsification with oscillating and stationary membranes. Ind Eng Chem Res 49:3810-3817. Holdich RG (2012) Unpublished results.

Kukizaki M (2009) Shirasu porous glass (SPG) membrane emulsification in the absence of shear flow at the membrane surface: Influence of surfactant type and concentration, viscosities of dispersed and continuous phases, and transmembrane pressure. J Membr Sci 327:234-243.

Nakashima T, Shimizu M, Kukizaki M (1991) Membrane emulsification by microporous glass. Key Eng Mater 61-62:513-516.

Nakashima T, Shimizu M, Kukizaki M (1993) Effect of surfactant on production of monodispersed O/W emulsion in membrane emulsification. Kag Kog Ronbunshu 19:991997.

Vladisavljević GT, Lambrich U, Nakajima M, Schubert H (2004) Production of O/W emulsions using SPG membranes, ceramic $\alpha-\mathrm{Al}_{2} \mathrm{O}_{3}$ membranes, microfluidizer and a microchannel plate: a comparative study. Colloid Surf A 232:199-207.

Vladisavljević GT, Williams RA (2005) Recent developments in manufacturing emulsions and particulate products using membranes. Adv Colloid Interface Sci 113:1-20.

Vladisavljević GT, Williams RA (2006) Manufacture of large uniform droplets using rotating membrane emulsification. J Colloid Interface Sci 299:396-402. 